\title{
CONTRACT SPLITTING IN GOVERNMENT PROCUREMENT: THE TREND IN NIGERIA'S PROCUREMENT SYSTEM
}

\author{
Solomon I. Ifejika
}

(2018) 5:1 APPLJ 1

\begin{abstract}
From independence in 1960 till 2007, public procurement activity in Nigerian Federal Government was not regulated by any known formal legislation made by the National Assembly of the country. The system and practice was thus weak and characterized by avalanche of irregularities and illegalities; massive corruption and fraud beset government procurement and contract award system in Nigeria throughout the period. Against this backdrop, in 2007, Nigeria through the National Assembly enacted a public procurement law- the Public Procurement Act (PPA), 2007, which ushered the country into a new procurement order. The PPA, 2007 aims to regulate the processes leading to award and implementation of all government procurement contracts in the Federal Government, with the view to forestalling the inadequacies of the old procurement practice. The paper argues that, despite the PPA, 2007, contract splitting, one of the major ills that saw the collapse of the old procurement system, has continued to show its ugly face under the current procurement dispensation. The paper uses some recent cases of contract splitting perpetrated by some Ministries, Departments and Agencies (MDAs) of Nigerian Federal Government to concretize its claims. It submits that Nigeria needs to take urgent measures to curb the odious trend so as to enable country to quickly realize the objectives of the recent public procurement reform. Accordingly, the paper recommends among other things, that strong 'political will' by the federal executive arm of government and unfettered application of the provisions of the law in handling cases of contract splitting by designated court - the Federal High Court of Nigeria are of high imperative in combating the malfeasance. The paper depends mainly on evidences from newspaper reports and speeches as sources of its data.
\end{abstract}




\section{CONTRACT SPLITTING IN GOVERNMENT PROCUREMENT: THE TREND IN NIGERIA'S PROCUREMENT SYSTEM}

Solomon I. Ifejika

Department of Political Science, University of Ilorin, Nigeria

\section{Introduction}

Public procurement is critical to development in all countries, developed and developing nations alike. Procurement is the means by which governments deliver essential public developmental goods and services to the citizens and for the day-today execution of governance affairs. Indeed, "governments all over the world are known as the greatest providers of services or public goods to the civil society". 1 Public procurement constitutes an important economic activity for every government as it accounts for the largest share of yearly public expenditure at all levels of government in every country. However, the risks of corruption and frauds are very high in public procurement due to the huge financial outlays in that sphere. These risks are inherent in public procurement systems in all countries, but they are presumed to be higher in development countries owing to inadequate practices and weaknesses of legal frameworks and regulatory institutions. Regulation is widely considered as an integral component of any standard public procurement policy frameworks. Adequate regulation reduces the possibilities of corruption and fraudulent practices and promotes the efficiency and effectiveness of the system.

Prior to 2007, public procurement activity in the Nigerian Federal Government was not regulated by any law enacted by the National Assembly of the country. As a result, the country's procurement practice and system was marred by massive corruption and irregularities. Fayomi corroborates this assertion as she argues that, "since independence of Nigeria in 1960, the country has been experiencing a high degree of mismanagement of resources particularly in the area of public procurement". ${ }^{2}$ As Achua rightly observes, "resources and funds that could go into infrastructure,

\footnotetext{
${ }^{1}$ Fayomi 2013: 40.

${ }^{2}$ Fayomi 2013: 40.
} 
education, and other essentials integral to development end up lining someone's pocket due to the effects of corruption". ${ }^{3}$ Government officials used procurement and contract award to reward their friends and cronies as well as amass wealth illegally. ${ }^{4}$ There were sharp practices such as over-invoicing, inflation of contract costs, and proliferation of white-elephant projects and diversion of public funds through all kinds of manipulation of the contract system. ${ }^{5}$ Also prominent among the corrupt practices in the Nigerian procurement system were contract splitting, collusion, poor projects designs, excessive delay in delivering of public works, delivery of substandard goods and works, and lack of accountability and transparency in contract award and execution process.

The unsatisfactory scenarios in the country's procurement system raised immense concerns both on the part of the government and citizens. Thus, on assumption of office in 1999, following the return of Nigeria to democratic rule, the then-President Olusegun Obasanjo demonstrated displeasures regarding the ways public resources were being embezzled, mismanaged or wasted, especially through contracts awards and implementation. The World Bank had also issued a directive, urging borrower member nations to review and analyze their existing procurement policies, organization, and procedures as part of its Country Assistant Strategies (CAS). The aim was and is still to help borrower nations develop or modify their systems in order to increase their capacity to plan, manage and monitor their procurement process effectively, as well as to improve the accountability, integrity and transparency of the process, reduce the scope of corruption, and be consistent with internationally acceptable principles and practices. ${ }^{6}$ Given the internal and external pressures for procurement reforms, therefore, the Obasanjo's administration in 1999 commissioned the Country Procurement Assessment field work. ${ }^{7}$ The exercise was conducted by the World Bank along with Nigerian home-based experts and professionals.

In the end, the World Bank-led team produced the report of its assessment of Nigerian procurement system - the Country Procurement Assessment Report (CPAR). Prominent among the key recommendations of the CPAR were the need for

\footnotetext{
${ }^{3}$ Achua 2011: 324.

${ }^{4}$ Jacob 2010:131.

${ }^{5}$ Fayomi 2013: 40.

${ }^{6}$ World Bank 2002:1.

${ }^{7}$ Onyema 2011.
} 
promulgation of a modern law on public procurement and establishment of an institution or agency to administer the law and regulate the process leading to award and implementation of procurement contracts in the country. Upon this premise, the Public Procurement Bill was sent to the National Assembly in 2003/2004, and passed into Law on May 31, 2007. On June 4, 2007, it was subsequently signed into Law by the then-President Umaru Musa Yar'adua and remains in operation to date. The Public Procurement Act (PPA), 2007 thus establishes the Bureau of Public Procurement (BPP) to be its main driver. ${ }^{8}$ The PPA is a composite law, containing all important provisions on conduct of public procurement based on internationally acceptable standards. Importantly, the Act clearly provides extensively on issues bordering on corruption and malfeasances in public procurement.

Specifically, the PPA, 2007 captures contract splitting as one of the offences punishable under the law. However, despite the position of the PPA, 2007 on contract splitting, in terms of its prohibition and clearly stipulated accompanying penalties, the trend has continued to occur in the current procurement environment in Nigeria as Ministries, Departments, and Agencies (MDAs) persistently indulge in contract splitting. This paper, therefore, primarily demonstrates that the malaise of contract splitting has not ceased to manifest in the current procurement dispensation in Nigeria, despite the existence of the new law on public procurement - the PPA, 2007. To achieve this principal objective, the rest part of the paper is structured into five sections. Section two consists of conceptual clarification or definition of contract splitting. Section three examines the position of Nigerian Public Procurement Act, 2007 on contract splitting. Section four provides evidence regarding the persistence of the malfeasance - contract splitting in the new public procurement system in Nigeria. Section five recommends some workable measures for combating the trend, while section six concludes the paper.

\section{Contract Splitting: A Conceptual Elucidation}

Contract splitting is also variously called or referred to as 'split purchase', 'split transaction', 'cost splitting', 'tender splitting' among others. Whichever tag forms the preferred choice of the definer, the point is that the meaning of the term remains the

\footnotetext{
${ }^{8}$ Onyema 2011.
} 
same. For instance, according to the United States Office of Personnel Management (US OPM), contact splitting entails internationally dividing a single purchase into two or more separate purchases to avoid exceeding the single purchase limit or to avoid competition. ${ }^{9}$ Similarly, in Nigeria, the Public Procurement Regulations for Goods and Works defines it as, splitting a contract into smaller units in order to avoid competitive bidding or distributing it among different bidders to enlarge bidder participation at lesser economic cost and efficiency. ${ }^{10}$

Further, the PPA, 2007 explains it in terms of "splitting of tenders to enable the evasion of set monetary thresholds". ${ }^{11}$ The conception of the term by the Fiji Procurement Office is in tandem with the above definition. It defines the term thus:

"Contract or costs splitting is a method of dividing the total procurement for a particular item or from a single supplier resulting in the reduction of the total sum of procurement to below the limits of legislated approval procurement authorities stipulated in the Procurement Regulations 2010 and Financial Manuals." 12

In view of the foregoing definitions, contract splitting in government procurement, in the context of this paper, refers to a condition whereby works, goods or services by government entities are deliberately divided among a number of contractors or vendors either in order to prevent competition or to keep cost below the amount specified by law. The act is prohibited under procurement laws of most countries, and it is generally regarded as an aspect of corrupt practices in public procurement process.

\section{Contract Splitting: The Position of Nigerian Public Procurement Act, 2007}

As observed earlier, the new Nigerian public procurement law, the PPA, 2007, is a composite legislation governing all procurements and award of contracts at the federal government level in the country. The PPA thus contains all requisite provisions on public procurement regulation based on international standards. The PPA consists of detailed provisions relating to offences in public procurement, as well as

\footnotetext{
${ }^{9}$ US OPM 2008:25.

${ }^{10}$ PPRGW 2007: 599.

${ }^{11}$ PPA s 58(4) (d).

${ }^{12}$ FPO 2014:1.
} 
accompanying penalties. According to the PPA, the following shall constitute offences under this Act: ${ }^{13}$

“(a) entering or attempting to enter into a collusive agreement, whether enforceable or not, with a supplier, contractor or consultant where the prices quoted in their respective tenders, proposals or quotations are or would be higher than would have been the case has there not been collusion between the persons concerned;

(b) conducting or attempting to conduct procurement fraud by means of fraudulent and corrupt acts, unlawful influence, undue interest, favor, agreement, bribery or corruption;

(c) directly, indirectly or attempting to influence in any manner the procurement process to obtain an unfair advantage in the award of a procurement contract;

(d) splitting of tenders to enable the evasion of monetary thresholds set;

(e) bid-rigging;

(f) altering any procurement document with intent to influence the outcome of a tender proceeding;

(g) uttering or using fake documents or encouraging their use; and

(h) willful refusal to allow the Bureau or its officers to have access to any procurement records."

Accordingly, the PPA is clear on the various degrees of penalties or punishments applicable to the different categories of stakeholders or participants in the procurement process for contravening or violating the provisions of the law. Regarding private individuals or persons, the Act expressly stipulates as follows:

"Any natural person not being a public officer who contravenes any provision of this Act commits an offence and is liable on conviction to a term of imprisonment not

\footnotetext{
${ }^{13}$ Section 58 (4) (a-h)
} 
less than 5 calendar years but not exceeding 10 calendar years without an option of fine." 14

With respect to public officers, officers or staff of the Bureau of Public Procurement (BPP), Ministries, Departments, and Agencies of government, the PPA states thus:

"Any person who while carrying out his duties as an officer of the Bureau, or any procuring entity who contravenes any provision of this Act commits an offence and is liable on conviction to accumulative punishment of: (a) a term of imprisonment of not less than 5 calendar years without any option of fine; and (b) summary dismissal from government services." 15

For companies or business entities, the Act specifies that:

"Any legal person that contravenes any provision of this Act commits an offence and is liable on conviction to accumulative penalty of: (a) debarment from all public procurements for a period not less than 5 calendar years; and (b) affine equivalent to $25 \%$ of the value of the procurement in issue." 16

The Act goes further to state as follows:

"Where any legal person shall be convicted pursuant to subsection (4) of this Section, every director of the company as listed on its records at the Corporate Affairs Commission shall be guilty of an offence and is liable on conviction to a term of imprisonment not less than 3 calendar years but not exceeding 5 calendar years without an option of fine."17

From the foregoing, it is clear that the PPA, 2007 clearly articulates practices that constitute offences under the law as well as appropriate punishments or penalties to be imposed on offenders. Specifically, subject to sub-section (4) (d) of Section 58 of the Act as evident above, contract splitting is a public procurement offence, and it is therefore punishable under the law. ${ }^{18}$ The law, as can be seen in Sections 58 subsections (1), (5), and (6) above spells-out severe punishments for private individuals,

\footnotetext{
${ }^{14}$ Section $58(1)$

${ }^{15}$ Section $58(5)$.

${ }^{16}$ Section $58(6)$.

${ }^{17}$ Section 58 (7).

18 PPA, 2007.
} 
companies/firms, and public officers who contravene the provisions of the Act. ${ }^{19}$ The penalties are supposed to serve as deterrents to would-be violators of the procurement law. Despite this, however, officials of MDAs in Nigeria continue to indulge in illegal practices including contract splitting, as against the law. The section below demonstrates this claim using some reported cases of contract splitting by some Federal Government MDAs in Nigeria.

\section{Contract Splitting in Nigeria: Continuing Trend in the New Public Procurement System}

Despite the reforms in the procurement system and enactment of the PPA, 2007, to ensure adequate regulation of processes in award and implementation of contracts in the Nigerian Federal Government, MDAs have continued to indulge in violation of the procurement laws. Specifically, some Federal Government MDAs have recently been reported to have engaged in contract splitting, a practice prohibited under the PPA.

To lend credence to this claim, the Office of Auditor General of the Federation indicted the Ministry of Petroleum Resources for contract splitting, violation of the procurement law and other offences. In its 2015 Audit Report, the Office of the Auditor General unequivocally stated that the Permanent Secretary of Ministry of Petroleum Resources violated some aspects the Public Procurement Act in the award of certain contracts and payments made in 2015. ${ }^{20}$ The report by the Office of the Auditor General disclosed that an expenditure entry of $\mathrm{N} 18.912$ million was made in the cashbook of the Ministry as payments to 11 corporate entities for different services rendered. ${ }^{21}$

Explaining the malfeasance by the Ministry in detail, the report stated that:

"the Ministry, in the award of contract for the supply of Schneider biros worth N14.574 million, split the contract into smaller packages of less than N5 million each and awarded to four different companies in order to circumvent the Permanent Secretary's approval threshold of N5 million."22

\footnotetext{
${ }^{19}$ PPA, 2007.

${ }^{20}$ See Eboh 2017; Business News Report 2017.

${ }^{21}$ Eboh 2017; Business News Report 2017.

22 Eboh 2017; Business News Report 2017.
} 
It also reveals that, "the contract for the printing of the Ministry's Letter-Headed paper worth N46.645 million was also split and awarded to 11 different contractors, while the contract for supply of toners worth N56. 418, million was split and awarded to 17 (Seventeen) different contractors." 23 The Auditor General brings to the fore the argument that action of the Permanent Secretary is in clear contravention of Section 20 (e) of the PPA in respect of tender splitting. ${ }^{24}$ This is true, in that the PPA states that:

"The accounting officer of a procuring entity shall be the person charged with line supervision of the conduct of all procurement processes; in the case of ministries the Permanent Secretary and in the case of extra-ministerial departments and corporations the Director-General or officer of co-ordinate responsibility." 25

Moreover, the PPA stipulates that:

"The accounting officer of every procuring entity shall have overall responsibility for the planning of, organization of tenders, evaluation of tenders and execution of all procurements and in particular shall be responsible for" ... "ensuring that no reduction of values or splitting of procurements is carried out such as to evade the use of the appropriate procurement method". ${ }^{26}$

In view of these unambiguous provisions, the Permanent Secretary of the Ministry of Petroleum Resources violated the procurement law.

Further, the Auditor General's Office in the same report disclosed "that the consultancy contract awarded to a company for local training/workshop for officers on Grade Level 07 to 10 in 2014, at a total cost of N11.214 million, was split into three and awarded the same day, November 24, 2014". ${ }^{27}$ The worth of the contract is in excess of the limit approved by the BPP for Ministries in respect of consultancy services. Undoubtedly, "The Bureau of Public Procurement (BPP) in its approved revised threshold for service wide application provides that Accounting Officers of Ministries

\footnotetext{
${ }^{23}$ Eboh 2017; Business News Report 2017.

${ }^{24}$ Eboh 2017; Business News Report 2017.

${ }^{25}$ Section 20 (1)

${ }^{26}$ Section $20(2)(\mathrm{e})$

${ }^{27}$ Eboh 2017; Business News Report 2017.
} 
can only exercise authority for consultancy services less than N5 million". ${ }^{28}$ The splitting of the consultancy contract into three by the Permanent Secretary is also in violation of the provision of Section 20(e) of the PPA, 2007 regarding tender splitting. ${ }^{29}$ It is also a disregard for the BPP-established thresholds.

Another case in reference is the one involving corruption charges before a Federal High Court in Lagos against former Director-General of the Nigerian Maritime Administration and Safety Control (NIMASA), Mr. Temisan Omatseye, who was suspended from his office to pave way for thorough investigation of the allegations against him on contract splitting at the agency. Mr. Temisan Omatseye has a 27 amended count charges preferred against him by one of Nigeria's major anticorruption agencies, the Economic and Financial Crime Commission (EFCC). ${ }^{30} \mathrm{He}$ was accused of fraud bordering on contract splitting involving about N1.5 billion which contravenes Section 58 (4)(d) of the Public Procurement Act, 2007 and Section 14(a) of the Nigerian Money Laundering (Prohibition) Act, 2004..$^{31}$

Two of Nigeria's oldest Federal Universities, the University of Nigeria, Nsukka and the University of Ibadan, respectively, have also been indicted for the same crime. The former Vice-Chancellor of the University of Nigeria, Nsukka, Professor Bartho Okolo, was found to have grossly violated procurement rules and perpetrated illegal practices, including contract splitting. Indeed, available records demonstrate that there were large-scale manipulations of processes leading to the award of the University's contracts during Professor Okolo's tenure as Vice-Chancellor of the University of Nigeria. ${ }^{32}$ Findings show that:

"These frauds usually involved multiple splitting of contracts perpetrated by the Vice-Chancellor without regard to the financial regulations of the University and the various laws governing the expenditure of public funds in Nigeria". ${ }^{33}$

\footnotetext{
${ }^{28}$ Eboh 2017; Business News Report 2017.

${ }^{29}$ Eboh 2017; Business News Report 2017.

${ }^{30}$ See Ibrahim 2015.

${ }^{31}$ Ibrahim 2015.

${ }^{32}$ See SaharaReporters 2011.

${ }^{33}$ SaharaReporters 2011.
} 
The former Vice-Chancellor resorted to indiscriminate splitting of contracts into several parts, a practice explicitly illegal and prohibited under both the University of Nigeria Financial Regulations and the Nigerian PPA, 2007. ${ }^{34}$

More worrisome, in this case, is the claim that this wrongdoing by the former University of Nigeria Vice-Chancellor was abetted. As claimed:

"This fraud by Professor Bartho Okolo was brought to the attention of the Governing Council of the University at its 221st Meeting held on September 16 and 17, 2010. Although the Council, according to the minutes of the said meeting expressed shock at such fraudulent contract splitting, it opted to abet this fraud by keeping mute...The Chairman of the Council, Professor S.O. Igwe, led some other council members in pleading this position." 35

It is argued that:

"The obvious reason for the failure of the Governing Council to do its job by applying the laws of the land to a fraudulent Vice Chancellor is that the Council has been compromised. The collusion of the University Council in this fraud is not surprising especially given the fact that professor lgwe, who was the academic face of the General Abacha one million man match several years ago, is well known for his fraudulent antecedents. Specifically, he was himself the champion of similar contract splitting practices when he was the Vice Chancellor of Abia State University in Uturu. In this regard, it would be recalled that a January 29, 2000 Government White Paper in the Report of the Visitation Panel to Abia State University Uturu from 1989 to 1999 ...noted as follows: The panel observed that the former Vice Chancellor Prof. S.O. Igwe devised means of manipulating the Internal tenders Board by splitting contracts so that the contract sum will fall within the limit allowed the Vice Chancellor through the Internal Tenders Board by the Financial Regulation of the University." 36

\footnotetext{
${ }^{34}$ SaharaReporters 2011.

${ }^{35}$ SaharaReporters 2011.

${ }^{36}$ SaharaReporters 2011.
} 
It becomes understandable why the claim that the fraud was covered by the University's Governing Council can be argued.

In the case of the University of Ibadan, findings show that, in addition to earlier report on how the University spent an overfunding of N5.1 billion, and a N649 million project implemented without relevant government approval, the OS Professional services (OSP) audit report has also revealed how the University of Ibadan has been flagrantly violating the provisions of the PPA, 2007, University of Ibadan Financial Instructions (January 1992), University of Ibadan Tender Manual (January 1992), Fiscal Responsibility Policy Act 2007, University of Ibadan Act of 1962 and Universities Miscellaneous Act 2003. ${ }^{37}$ These abuses of relevant regulations by the University of Ibadan include, award of contract to unregistered companies, illegal contract splitting, bid rigging and others. In addition to the acknowledged fact that Section 58(4) of the PPA, 2007 criminalizes splitting of contracts, the University Tender Board approval limit is below two-hundred and fifty million naira (N250 million) and any contracts estimated or valued above this limit must secure ministerial tender board approval from the Ministry of Education before such contracts can be awarded. ${ }^{38}$

In what can be described as a disobedience to laws, revelations demonstrate that:

"It has been uncovered in the recent audit report by OS Professional services (OSP) that Halix Matrix Ltd and MM \& IF Integrated Ltd got a split contracts for the construction of building for virology department phase 1 and phase 2 respectively. The contract, which was awarded on the same date, May 28, 2015 went for $\mathrm{N} 153,399,568.63$ and $\mathrm{N} 140,612,709.19$, an addition of which gives N294,012,277 which obviously is above the threshold limit of N250,000,000."39

It is also reported that:

"Contracts for the Purchase and Installation of electrical control/Protection Devices for University of Ibadan and Purchase of Fault Detectors for the University of

\footnotetext{
${ }^{37}$ See Oredola 2017.

${ }^{38}$ Oredola 2017.

${ }^{39}$ Oredola 2017.
} 
Ibadan were awarded to Debson Engineering Company Ltd and Elgar Nigeria Limited for N206,613,330.00 and N53, 942,991.30 respectively. This adds up to $\mathrm{N} 260,556,321.00$ and it is obvious that the two contracts were intentionally split to avoid having to get a Ministerial Tender Board approval." 40

Investigation further reveals that Halix Matrix Ltd and MM \& IF Integrated Ltd, the two companies that got a split contracts worth of N294,012,277, for the construction of building for virology department phase 1 and phase 2, were not registered with the Corporate Affairs Commission. ${ }^{41}$ These reported cases involving Nigeria's two premier Universities apparently signals a dimmed hope for the country in terms of the possibility of developing the essential public sector ethos of strict adherence and respect for established statutes. Since the university system that is supposed to champion the advocacy for the rule of law in the conduct of government business is itself indicted in these types of criminal activities and disregard for rules, less or nothing would thus be expected of other sectors of the economy.

Similarly, the Registrar/Chief Executive of Nigeria's National Business and Technical Examinations Board (NABTEB), Professor Ifeoma Isuigo-Abanihe and four officials of the agency were suspended over allegations of contract splitting and other offences. The four staff/officials of the agency suspended along their boss include: Mr. Nnasia, Ndarake Asanga (Director, Finance and Accounts), Dr. Obinna M. Opara (Director, Examination Administration), Alhaji Jimoh Adewola Kasali (Director, Examinations Development) and Engr. Edwin Osamo (Procurement Officer). ${ }^{42}$ The suspension followed the report of a special investigative panel constituted to probe the activities of the NABTEB Registrar/Chief Executive, Professor Ifeoma Isuigo-Abanihe, which uncovered irregularities in contract awards and abuse of office by the Registrar. ${ }^{43}$ The NABTEB Registrar and affected four staff of the agency were suspended by the 9th Governing Board of NABTEB at its first regular Board meeting held on 19th June, 2018, at NABTEB headquarters, Benin City, Edo State, as a result of allegation of fraud and refusal to open her books upon request by the Board's Chairman, Prof. Leonard Karshima Shilgba. ${ }^{44}$ Documents from the Federal Ministry of Education and

\footnotetext{
${ }^{40}$ Oredola 2017.

${ }^{41}$ Oredola 2017.

${ }^{42}$ See Ikpefan 2018; Olajide 2018.

${ }^{43}$ Olajide 2018.

${ }^{44}$ Olajide 2018.
} 
the Committee indicated that the administration of the NABTEB Registrar, Prof. IsuigoAbanihe, have been involved in breaches of procurement rules, misappropriation of funds, illegal recruitment and other irregularities. ${ }^{45}$

Specifically, on violation of procurement process, the investigative panel scrutinized contract awards by the Registrar between 21st February to 14th March 2018 and found that 42 contracts amounting to the sum of N154,813,432.00 were split into 15 separate contracts for printing and 14 separate contracts for the supply of HP LaserJet Toner. Other contracts for the supply of printers, hard-drives, DDR Roms, office flat files, envelops, Kalamazoo binders, photocopying machines and Risograph machines, among others were split into units among suppliers, and neither the unit costs nor the quantities of these items were specified. ${ }^{46}$ In addition to the crime of splitting the contracts, it is observed that the processes of awarding those contracts were not subjected to the due process mechanisms. As it is stated:

"The contracts did no go through due process. The awarding authority in this respect was the Management Tenders Board. The contract were hurriedly awarded, split into units and were not given to the President through the Ministry of Education for approval as the amount involved was beyond the powers of the Management Tenders Board." 47

Thus, besides its criminal status under the Nigerian public procurement law, the act by the NABTEB Registrar/Chief Executive, Prof. Isuigo-Abanihe, is also considered a violation of the NABTEB Standing Order. It is held that:

"The Registrar is guilty of Contract splitting without obtaining approval from the supervisory ministry as stipulated in NABTEB Standing Order 18 and 19 N. Section 18 states that all services and goods (e.g. printing, supplies or purchases) contracts above N2.5 million, and all works (e.g. contracts from N5 million and above shall receive the final approval of the Governing Board)." 48

\footnotetext{
${ }^{45}$ Olajide 2018.

${ }^{46}$ Olajide 2018.

${ }^{47}$ Olajide 2018.

${ }^{48}$ Olajide 2018.
} 
And there shall be no splitting of contract for the same services or goods (e.g. printing, supplies or purchases) contract the sum worth of whose split is above N2.5 million, and for the same works (e.g. construction, renovation or refurbishing projects) contract the sum of whose splits is N5 million or more without the approval of the Governing Board. Section 19 states that NABTEB Tenders Board shall not be the final clearance or approval authority for the contracts and expenditures that the management of NABTAEB enters into. All approvals of NABTEB Tenders Board shall be forwarded to the Governing Board of NABTEB for consideration and approval. ${ }^{49}$

The above scenarios provide enough evidence to the effect that, despite the enactment of the PPA, 2007, to curb corrupt practices and forestall the re-occurrence of the inadequacies of Nigeria's old procurement practice in the current public procurement system, MDAs of the Federal Government have continued to sabotage the efforts. The prevailing situation implies that MDAs are yet to accept the reforms carried-out by the Federal Government of Nigeria in the country's procurement system whole-heartedly. In other terms, there is yet low levels of compliance with the PPA, 2007 by MDAs, and this poses a significant challenge to the realisation of the objectives of the reform of the country's procurement system and practice. The above situation in Nigeria validates the argument by former-President Olusegun Obasanjo that:

"Lack of integrity in our national life is causing us a lot of potential and it is the grandfather of corruption. It is responsible for the high cost of governance. Contract splitting is now the order of the day. Companies doctor their annual reports to suit business purposes. Public office holders engage in procurement distortions and these have led to the huge institutional inefficiency, infrastructure and social decay we are experiencing today." 50

Most disturbing, is that, no single individual offender of the public procurement law, specifically in relation to the offense of contract splitting, has been duly prosecuted and punished according to law, since the PPA, 2007 came into effect in June, 2007. Yet, news of perpetration of the prohibited practice by top public management

\footnotetext{
${ }^{49}$ Olajide 2018.

${ }^{50}$ Ubabukoh 2018.
} 
officials/staff of Federal Government MDAs in Nigeria, continue to make headlines on national dailies, thereby posing fundamental challenge to the main rationale for the enactment of the Public Procurement Act.

\section{$5 \quad$ Combating the Objectionable Trend}

There is the utmost need to combat the prevailing trend of contract splitting in Nigerian public procurement system, as a matter of urgency, so as to guarantee adequate attainment of the objectives of the recent procurement reform and aims of the PPA, 2007. In light of this, the paper recommends the following workable measures to enable Nigeria to address the malfeasance of contract splitting:

As the main driver and custodian of the new public procurement law in Nigeria, the PPA, 2007, the BPP needs, in accordance with Section 5(d) of the Act, to begin to ensure proper and closer monitoring and supervision of procurement processes in all MDAs of the Federal Government. Periodic conduct of audit on records of procurement activities of MDAs, as Section 5(p) of the PPA, 2007 mandates and empowers the BPP, will aid the entire process. More specifically, the BPP should begin to pay adequate attention to detecting 'Red-Flags' of contract splitting and related corrupt practices by MDAs at different stages of award and execution of government procurement contracts.

The executive arm of the Nigerian Federal Government needs to demonstrate its determination to address the issue of corruption in public procurement and violation of the provisions of the PPA, 2007, by exhibiting strong political will in dealing with such offences by public officials. No matter how highly connected those alleged to be involved may be, and regardless of their political affiliations, the executive should ensure that the law takes its due course. This is essential, because the more the seriousness on the part of the political executive to address these issues, the greater the sense of discipline and fear that would be instilled in the perpetrators of the PPA, 2007.

Being the appropriate court of jurisdiction for the handling of cases of violation of the PPA, 2007, according to Section 58 (2) of the Act, the Federal High Court of Nigeria should, henceforth, begin to ensure prompt arraignment and speedy prosecution of alleged culprits. Upon adequate trial, those found guilty should be apportioned 
appropriate punishment in accordance with the law, without allowing any sorts of interference; the court should ensure unfettered enforcement of the law. Moreover, judicial personnel with responsibility to adjudicate over alleged cases of violation of the PPA should be persons of proven impeccable characters, who would not sacrifice justice for personal material gains, if lured to collect bribes to avert judgment. This is imperative in combating the unwholesome trend.

A re-orientation and proper sensitization of staff/officials of procuring entities, MDAs of the Federal Government, by the BPP, on contract splitting will also impact greatly on efforts at combating the wrongdoing. By virtue of Section $5(k)$ of the PPA, 2007, the BPP has the functional responsibility to organize training and development programmes for the Procurement Officers of MDAs. Thus, the BPP should utilise this avenue to deliberately educate MDAs' staff, not only on the legal implications of being found guilty of contract splitting by the court, but also on the negative effects of the unhealthy practice on the delivering of public works, goods, and services with taxpayers' money. This could be in the form of workshops and seminars organized specifically for the purpose. This, obviously, will in no small measure help in curtailing the unhealthy trend.

\section{Conclusion}

Contract splitting was one of the ills that saw to the collapse of the old public procurement practice and system in Nigeria. Consequently, following the reforms instituted and successfully implemented in the country's public procurement system, which ushered-in a new procurement regime based on the PPA, 2007, the practice has come to be formally recognized as a criminal offence punishable under the law. As evident in the body of the paper, the PPA clearly spells out various degrees and forms of punishments applicable to private persons, companies or contracting firms, as well as public officials, who violate any provisions of the procurement law, including abuse of the provision related to contract splitting. However, as finding of this study shows, despite the wide acknowledgement of the position of the PPA on contract splitting, that is, its prohibition by the law, many top management officials/staff of Federal Government MDAs in Nigeria have continued to indulge in the malfeasance. The trend, as it stands, poses serious obstacles to the achievement of the objective of the public procurement reform and the aim of enacting the PPA, 2007. Notwithstanding 
the prevailing situation, the present author is optimistic that the trend can be absolutely combated if relevant authorities wholly adopt and properly apply the recommendations put forward by this paper. 


\section{Bibliography}

Achua, J. K., 2011. Anti-Corruption in Public Procurement in Nigeria: Challenges and Competency Strategies. Journal of Public Procurement, 11 (3), 323-353.

Business News Report, 2017. AuGF queries petroleum ministry for contract-splitting, procurement violation. Business News Report, (online) 11 September. Available at: https://www.businessnewsreport.com.ng/augf-queries-petroleum-ministry-contractsplitting-procurement-violation/(Accessed 9 October 2018).

Eboh, M., 2017. AuGF accuses petroleum ministry of contract-splitting, procurement violation. Vanguard News, (online) 19 September. Available at: https://www.vanguardngr.com/2017/09/augf-accuses-petroleum-ministry-contractsplitting-procurement-violation/ (Accessed 9 October 2018).

Faoyi, I. O., 2013. Public procurement and due process policy in Nigeria: Thrust, prospects and Challenges. Peak Journal of Social Sciences and Humanities, 1(4), 3945.

Public Procurement Regulations for Goods and Works 2007 (Nigeria).

Public Procurement Act 2007 (Nigeria).

Fiji Procurement Office, 2014. Splitting of Contracts. Suva: Ministry of Finance, Republic of Fiji.

Ibrahim, Y., 2015. N1.5bn fraud: Ex-NIMASA boss denies splitting Contracts. Daily Trust, (online) 10 November. Available at: https://www.dailytrust.com.ng/n1-5bnfraud-ex-nimasa-boss-denies-splitting-contracts.html (Accessed 19 October 2018).

Ikpefan, F., 2018. NABTAB registrar, four directors suspended for contract splitting, others. The Nation, (online) June 25. Available at: http://thenationonlineng.net/nabtebregistrar-four-directors-suspended-for-contract-splitting-others/ (Accessed 9 October 2018).

Jacob, A. O., 2010. Public Procurement law in Nigeria: Challenges for attainment of its Objectives. University of Botswana Law Journal, 11, 131- 151. 
Olajide, T., 2018. NABTAB Registrar, 4 Directors suspended over contract splitting. Financial Watch, (online) 24 June. Available at https://www.financialwatchngr.com/2018/06/24/nabteb-registrar-4-directorssuspended-over-contracts-splitting/ (Accessed 9 October 2018).

Onyema, M. E., 2011. Challenges and Prospects of Public Procurement Practice in Nigeria. NewsDiaryOnline, (online) 30 September. Available at: http://newsdiaryonline.com/procured.htm (Accessed 20 November 2013).

Oredola, I., 2017. Uncovered: How University of Ibadan awarded contract to unregistered companies, illegal contract splitting, bid rigging and others. The Page, (online) 4 July. Available at: http://thepageng.com/2017/07/04/uncovered-universityibadan-awarded-contracts-unregistered-companies-illegal-contract-splitting-bidrigging-others/ (Accessed 9 October 2018).

SaharaReporters, 2011. Contract Splitting Fraud and Cover up in University of Nigeria Nsukka. SaharaReporters, (online) 22 August. Available at: http://saharareporters.com/2011/08/22/contract-splitting-fraud-and-cover-universitynigeria-nsukka (Accessed 9 October 2018).

Ubabukoh, O., 2018. Nigeria may lose 30\% GDP to corruption - Obasanjo. Punch, (online) 2 July. Available at: https://punchng.com/nigeria-may-lose-30-gdp-tocorruption-obasanjo-2/ (Accessed 9 October 2018).

United States Office of Personnel Management, 2008. OPM Purchase Card Program - Contracting Policy 13.301. Available at: https://www.opm.gov/about-us/doingbusiness-with-opm/contracting-opportunities/policiesregulations/13301opmpurchasecardprogram.pdf (Accessed 9 October 2018).

World Bank, 2002. Revised CPAR Procedures. Office Memorandum, 23 May. 